\title{
Efficient plant regeneration of Malaysian aromatic rice (Oryza sativa L.) through somatic embryogenesis
}

\author{
Z. A. Rahman ${ }^{1 *}$, A. Ramli², H. Hosni², R. Kamaruzaman², Z. A. Seman³, A. N. Othman', Z. Zainal', J. Uddain ${ }^{5}$, \\ S. Subramaniam ${ }^{5}$ \\ ${ }^{1}$ Biotechnology Research Centre, MARDI Headquarters, Persiaran MARDI-UPM Serdang, Selangor Malaysia; ${ }^{2}$ Rice Industry Crop Centre, \\ MARDI Headquarters, Persiaran MARDI-UPM Serdang, Selangor Malaysia; ${ }^{3}$ Centre for Marker Discovery and Validation (CMDV) MARDI \\ Headquarters, Persiaran MARDI-UPM Serdang, Selangor Malaysia; ${ }^{4}$ Faculty of Science and Technology, Universiti Kebangsaan Malaysia, \\ 43600 UKM Bangi, Selangor; ${ }^{5}$ School of Biological Sciences, Universiti Sains Malaysia, 11800 Gelugor, Penang, Malaysia
}

\section{A B S TR A C T}

Aromatic rice variety namely MRO 74, MRO 80 and MRO 50 are the most popular rice in Malaysia. Establishing an efficient regeneration protocols via somatic embryogenesis is required for varietal improvements. An efficient somatic embryogenesis system has been established for three aromatic rice varieties using mature seeds. MS-B5 medium containing $1 \mathrm{mg} / \mathrm{L} 2$, 4-D (2, 4-dichlorophenoxyacetic acid) and $10 \mathrm{mg} / \mathrm{L}$ NAA ( $\alpha$-naphthaleneacetic acid) optimized that produced highest embryogenic callus (89\%) without any browning effect. The highest whitish somatic embryos frequency $(75 \%)$ was initiated by incubating embryogenic calli on same medium containing $10 \mathrm{mg} / \mathrm{L}$ ABA and $9 \mathrm{~g} / \mathrm{L}$ Gelrite for 8 weeks. However, the numbers of regenerated plantlets on medium containing NAA and 2,4-D which was previously pre-treated with $10 \mathrm{mg} / \mathrm{L} \mathrm{ABA}, 9 \mathrm{~g} / \mathrm{L}$ Gelrite and incubation at 8 weeks was the best method for shoots induction of three rice varieties.

Keywords: Aromatic rice; Somatic embryogenesis; Plant growth regulators; Carbon sources

\section{INTRODUCTION}

Rice (Oryza sativa L.) is one of the most important cereal crop and a primary food source for half of the world's population. Aromatic rice is also named as fine rice, scented rice or fragrance rice. It is very popular in Asia as well as Southeast Asia and has recently gained wider acceptance in the Middle East and Western communities (Sarhadi et al., 2008; Myint et al., 2009; Sakthivel et al., 2009; Hashemi et al., 2015). Aroma is considered one of the most important traits for rice grain quality and MRQ 74, MRQ 80 MRQ 50 are the most popular aromatic rice in Malaysia (Hashemi et al., 2015). Numerous varieties of rice are aromatic, ranging from the famous Basmati to the lesser known Randhunipagal (Mo et al., 2015). Strong fragrance expression plays a significant role in rice trading. Aromatic or scented rice plays a vital role in global rice trading for increasing consumers demand and attractive price (Sakthivel et al., 2009; Hashemi et al., 2013).

Rice improvement through biotechnological approaches depend on an efficient protocols through, in vitro callus induction as well as a suitable regeneration protocols (Vega et al., 2009; Khatun et al., 2012; Siddique et al., 2014). In vitro rice regeneration can be accomplished through somatic embryogenesis and organogenesis. Somatic embryogenesis of rice is one of the most promising approaches for rapid propagation due to production of large numbers of plantlets and for the application of genetic transformation technology especially against biotic stresses (Zuraida et al., 2011). The success of somatic embryogenesis is highly influenced by a suitable genotype, growth medium, plant growth regulators (PGRs), carbon sources and gelling agent affect the somatic embryogenesis as well as plant regeneration of rice (Deo et al., 2010).

Auxin such as 2,4-D or NAA plays a vital role for cell diversity in callus culture (Su et al., 2009; Cheng et al., 2010; Ding et al., 2010; Rademacher et al., 2012). Auxin stimulates the somatic embryogenesis and plant regeneration on rice callus culture (Vega et al., 2009). Auxin considered as a key factor in somatic embryogenesis which influences osmotic prerequisite and carbohydrate metabolism on shoot regeneration (Lee and Huang, 2014). Huang et al.

\section{${ }^{*}$ Corresponding author:}

Zuraida Abdul Rahman, Biotechnology Research Centre, MARDI Headquarters, Persiaran MARDI-UPM Serdang, Selangor Malaysia. E-mail: azuraida@mardi.gov.my. 
(2012) highlighted that endogenous auxin stimulate shoot regeneration in rice calli. Abscisic acid (ABA) supplemented medium produces high quality somatic embryos by decreased osmotic water potential compared to the maintenance medium (Klimaszewska et al., 2000; Pérez et al., 2015). Osmotic water potential depends on types of media, carbon sources and gelleting agent concentrations (Hadeler et al., 1995; Klimaszewska et al., 1997; Laine et al., 2000; Triqui et al., 2008).

Hence, selection of appropriate in vitro growth medium supplemented with carbon sources and plant growth regulators are essential prerequisite for embryogenic callus culture which is influences on the genetic improvement of aromatic rice. In the present work, we have established an efficient callus induction and regeneration protocol for Malaysian aromatic rice of MRQ 80, 50 and 74 via somatic embryogenesis system.

\section{MATERIALS AND METHODS}

\section{Plant materials}

Mature seeds of three Malaysian aromatic rice varieties of MRQ 50, MRQ 74 and MRQ 80 were used for the initiation of an embryogenic callus and plant regeneration. Mature dehusked seeds were sterilized sequentially with $100 \%$ ethanol for $2 \mathrm{~min}$. and 50\% (v/v) clorox (sodium hypochlorite $5.25 \%$ ) supplemented with 1-2 drops of Tween-20 for 30 min. with shaking, and were then rinsed three times thoroughly with sterile distilled water.

\section{Embryogenic callus induction medium}

For embryogenic callus induction three basal media, MS (Murashige and Skoog, 1962), MS-B5 (MS with B5 vitamin) and N6 (Chu, 1975) were used that supplemented with $3 \%$ sucrose, $0.3 \%$ gelrite, $1.5 \mathrm{mg} / \mathrm{L} \mathrm{BAP}$ and different concentrations and combination of 2, 4-D (1 and $5 \mathrm{mg} / \mathrm{L})$ and NAA ( 5 and $10 \mathrm{mg} / \mathrm{L}$ ). The $\mathrm{pH}$ of all media was adjusted to 5.80 with $1 \mathrm{~N} \mathrm{NaOH}$ or $\mathrm{HCl}$ prior to autoclaving for $15 \mathrm{~min}$ at $121^{\circ} \mathrm{C}$. Inoculated seeds were then incubated at $25 \pm 2^{\circ} \mathrm{C}$ in the dark condition and under cool-white fluorescent light of $30 \mu \mathrm{molm}^{-2} \mathrm{~s}^{-1}$ for 16 hours. Each treatment consisted of 10 seeds per plate with 20 plates and repeated 3 times. Data were recorded after 4 weeks of culture initiation and callus induction rate $(\%)$ was calculated as below:

Total number of cultured seed with callus-Total number of

Callus initiation $(\%)=\frac{\text { intiated callus }}{\text { Total number of cultured seed }} \times 100$

The fresh calli were transferred onto the same fresh medium and the percentage of browning embryogenic callus was calculated.

\section{Somatic embryogenesis}

The best callus induction medium (MS- B5) supplemented with $1.5 \mathrm{mg} / \mathrm{L} \mathrm{BAP,} 1 \mathrm{mg} / \mathrm{L}$ 2,4-D and $10 \mathrm{mg} / \mathrm{L} \mathrm{NAA}$ were used for somatic embryogenesis in this experiment. Selected high quality embryogenic callus were cultured that supplemented with $\mathrm{ABA}$ (5 and $10 \mathrm{mg} / \mathrm{L}$ ) for preregeneration purposes. Different concentrations of gelrite (3, 6, 9 and $12 \mathrm{~g} / \mathrm{L})$ were tested as a solidifying agent in pre-regeneration medium. Sucrose (10 and $30 \mathrm{~g} / \mathrm{L})$ and maltose (10 and $30 \mathrm{~g} / \mathrm{L})$ were used as a carbon sources and cultures were incubated in dark condition for 4 - 8 weeks to complete the pre-regeneration process. Data was recorded as the percentage of forming whitish embryos.

\section{Plant regeneration from somatic embryos}

Three grams (g) of the initiated 8 weeks old whitish embryos were cultured on MS-B5 medium supplemented with $1.5 \mathrm{mg} / \mathrm{L} \mathrm{BAP}, 1 \mathrm{mg} / \mathrm{L} \mathrm{2}$, 4-D, $10 \mathrm{mg} / \mathrm{L}$ NAA and $10 \mathrm{mg} / \mathrm{L} \mathrm{ABA}$ ) and tested on agar concentration (6 and $9 \mathrm{~g} / \mathrm{L})$ with carbon sources as sucrose $(10 \mathrm{~g} / \mathrm{L})$ and maltose $(30 \mathrm{~g} / \mathrm{L})$. The numbers of regenerated green plantlets were recorded within 8 weeks.

\section{Histological analysis}

Whitish embryos were fixed in a FAA solution for 1224 hours, dehydrated through a series of ethanol solution and embedded in paraffin wax. The specimen were sectioned at 3-4 $\mu \mathrm{m}$ and stained with $0.5 \%(\mathrm{w} / \mathrm{v})$ fast green and $0.25 \%$ $(\mathrm{w} / \mathrm{v})$ safranin. The stained samples were observed under a light microscope equipped with a camera connecting to the computer system.

\section{Statistical analysis}

All data were calculated by the mean of the three individual experiments. Each experiments were designed in CRD (Complete randomized design) which followed by four replicates. All mean data were analyzed by one way ANOVA via SPSS software version 20. Comparisons of the mean data and standard error (S.E) were determined by Turkey's multiple range tests at $\mathrm{P}<0.05$ level of significance.

\section{RESULTS AND DISCUSSION}

\section{Callus induction and percentage of browning}

The newly induced callus is a mass of unorganized parenchymatus cells derived from mature seeds after four weeks of culture. The significant effects on callus initiation of three Malaysian aromatic rice varieties (MRQ 74, 80 and 50) were evaluated using different callus induction media supplemented with 2,4-D and NAA (Table 1). In this study, 2,4-D (1 and $5 \mathrm{mg} / \mathrm{L})$ were tested either single or in combination with NAA ( 5 and $10 \mathrm{mg} / \mathrm{L}$ ) for callus initiation. Inclusion of 2,4-D supplemented with different callus induction media (N6, MS and MS-B5) resulted callus initiation 
varying from 41 to $84 \%$. The maximum callus initiation (84\%) were recorded from $5 \mathrm{mg} / \mathrm{L}$ 2,4-D supplemented with N6 medium of MRQ 74 whereas minimum initiation (41\%) were found in $1 \mathrm{mg} / \mathrm{L} 2,4-\mathrm{D}$ supplemented with MS medium for MRQ 74 and MRQ 80 (Table 1). The combined effect of 2,4-D and NAA influenced significantly for callus initiation of three rice varieties on different callus induction medium (Table 1). Callus induction ranged from 23 to $89 \%$ was found in this study. The highest callus induction (89\%) was recorded in MS-B5 supplemented with $1 \mathrm{mg} / \mathrm{L} 2,4-$ $\mathrm{D}$ and $10 \mathrm{mg} / \mathrm{L}$ NAA in MRQ 80 and the lowest (23\%) was determined as N6 and MS-B5 supplemented with $5 \mathrm{mg} / \mathrm{L} 2,4-\mathrm{D}$ and $10 \mathrm{mg} / \mathrm{L} \mathrm{NAA}$ in MRQ 50 and MRQ 74 respectively (Table 1 ).

Overall, the highest browning (75\%) occurred in MRQ 74 cultured in MS medium supplemented with $5 \mathrm{mg} / \mathrm{L} 2,4-\mathrm{D}$. MRQ 80 and MRQ 50 didn't detect any browning incidence form all media supplemented 2,4-D and NAA treatments but MRQ 74 displayed some degree of browning in all cultured media with 2,4-D and NAA. On the basis of result, MS-B5 medium supplemented with $1.5 \mathrm{mg} / \mathrm{L}$ BAP, $1 \mathrm{mg} / \mathrm{L} 2$, 4-D and $10 \mathrm{mg} / \mathrm{L} \mathrm{NAA}$ was suitable for callus induction of three rice varieties.

Callus initiation depends on basal media supplemented with different plant growth regulators. Kaushal et al. (2015) reported that 2,4-D initiated more callus compared to

\begin{tabular}{|c|c|c|c|c|c|c|c|c|}
\hline \multirow[t]{2}{*}{ Variety } & \multirow[t]{2}{*}{$\begin{array}{c}2,4-D \\
(\mathrm{mg} / \mathrm{L})\end{array}$} & \multirow[t]{2}{*}{$\begin{array}{c}\text { NAA } \\
(\mathrm{mg} / \mathrm{L})\end{array}$} & \multicolumn{3}{|c|}{$\begin{array}{l}\text { Callus } \\
\text { initiation } \\
(\%)\end{array}$} & \multicolumn{3}{|c|}{$\begin{array}{l}\text { Percentage } \\
\text { of browning } \\
\text { (mean } \pm S . E \text { ) }\end{array}$} \\
\hline & & & N6 & MS & MS-B5 & N6 & MS & MS-B5 \\
\hline \multirow[t]{6}{*}{ MRQ74 } & 1 & - & $53 \pm 7$ & $41 \pm 6$ & $63 \pm 5$ & $42 \pm 2$ & $60 \pm 12$ & $61 \pm 16$ \\
\hline & 5 & - & $84 \pm 5$ & $78 \pm 4$ & $81 \pm 8$ & $51 \pm 5$ & $75 \pm 7$ & $70 \pm 8$ \\
\hline & 1 & 5 & $63 \pm 8$ & $54 \pm 6$ & $79 \pm 11$ & $35 \pm 4$ & $55 \pm 5$ & $55 \pm 3$ \\
\hline & 1 & 10 & $41 \pm 7$ & $52 \pm 11$ & $84 \pm 8$ & $30 \pm 6$ & $50 \pm 5$ & $45 \pm 6$ \\
\hline & 5 & 5 & $47 \pm 6$ & $49 \pm 5$ & $41 \pm 4$ & $40 \pm 6$ & $55 \pm 6$ & $40 \pm 2$ \\
\hline & 5 & 10 & $11 \pm 2$ & $31 \pm 6$ & $23 \pm 5$ & $47 \pm 8$ & $47 \pm 11$ & $53 \pm 3$ \\
\hline \multirow[t]{6}{*}{ MRQ80 } & 1 & - & $64 \pm 9$ & $41 \pm 3$ & $56 \pm 4$ & $24 \pm 2$ & $15 \pm 3$ & $7 \pm 1$ \\
\hline & 5 & - & $78 \pm 8$ & $62 \pm 4$ & $77 \pm 11$ & $31 \pm 3$ & $5 \pm 1$ & $10 \pm 2$ \\
\hline & 1 & 5 & $61 \pm 6$ & $64 \pm 7$ & $84 \pm 4$ & - & - & - \\
\hline & 1 & 10 & $85 \pm 9$ & $82 \pm 15$ & $89 \pm 5$ & - & - & - \\
\hline & 5 & 5 & $41 \pm 5$ & $72 \pm 11$ & $52 \pm 3$ & - & - & - \\
\hline & 5 & 10 & $54 \pm 7$ & $34 \pm 5$ & $55 \pm 4$ & $5 \pm 0.5$ & $5 \pm 1$ & $5 \pm 1$ \\
\hline \multirow[t]{6}{*}{ MRQ50 } & 1 & - & $64 \pm 6$ & $55 \pm 2$ & $41 \pm 3$ & $24 \pm 5$ & $15 \pm 2$ & - \\
\hline & 5 & - & $71 \pm 6$ & $65 \pm 4$ & $64 \pm 7$ & $31 \pm 6$ & $5 \pm 0.5$ & - \\
\hline & 1 & 5 & $71 \pm 6$ & $74 \pm 15$ & $72 \pm 4$ & - & - & - \\
\hline & 1 & 10 & $83 \pm 9$ & $84 \pm 7$ & $74 \pm 7$ & - & - & - \\
\hline & 5 & 5 & $37 \pm 3$ & $46 \pm 5$ & $43 \pm 11$ & - & - & - \\
\hline & 5 & 10 & $23 \pm 2$ & $37 \pm 5$ & $45 \pm 4$ & $10 \pm 2$ & $10 \pm 3$ & $5 \pm 1$ \\
\hline
\end{tabular}

The data represent the mean values \pm standard error. Standard errors (SE) were determined by Turkey's multiple range tests at $P<0.05$ level of significance picloram in rice plant and concluded that 2,4-D is the most largely used growth regulator irrespective of the target materials for major cereal crops. Kaushal et al. (2014 a,b) highlighted that callus induction medium supplemented with 2,4-D initiated friable type of callus with low regeneration capability was produced in IR $58025 \mathrm{eB} \times$ Dular. Afrasiab and Jafar (2011) observed that MS medium supplemented with $2 \mathrm{mg} / \mathrm{L}$ 2,4-D initiated higher frequency of callus induction in Super Basmati rice. Rossin and Rey (2011) highlighted that $8 \mathrm{mg} / 12,4-\mathrm{D}$ and $12 \mathrm{mg} / 1$ picloram enhanced somatic embryogenesis in selected cassava cultivars. Ilahi et al. (2005) pointed out that several mixtures of auxins and cytokinins supplemented modified medium increased the embryogenic callus and effectively multiplied on MS accompanied with $1.0 \mathrm{mg} / \mathrm{L}$ of Kin and $0.5 \mathrm{mg} / \mathrm{L}$ of NAA. According to Jain et al. (1995), initiation of callus is influenced by several factors such as explants type and plant growth regulators particularly auxins and cytokinins. A similar phenomena was reported by Thengane et al. (2006) with addition of NAA (5.3-10.7 $\mu \mathrm{M})$ which gave rise to germinating embryos with complete well-developed shoots. In garlic, low level of 2,4-D increased the percentage of explants producing callus and subsequently tend to give rise to fine compact callus formation (Barandiaran, 1999).

\section{Effect of carbon sources, gelrite and ABA on somatic embryogenesis}

Proliferated embryogenic callus were cultured to MS-B5 medium supplemented with carbon sources (sucrose and maltose), different concentrations of gelrite and $\mathrm{ABA}$ to investigate their potentiality for somatic embryogenesis in MRQ 74, MRQ 80 and MRQ 50. After two months of culture, whitish somatic embryos were calculated as a percentage which derived from embryogenic callus. Compared to carbon sources, maltose helped to initiate more somatic embryos compared to sucrose and $10 \mathrm{~g} / \mathrm{L}$ maltose initiated highest number of somatic embryos in all rice varieties (Table 2).

MS-B5 medium supplemented with $3 \mathrm{~g} / \mathrm{L}$ Gelrite could not generate somatic embryos. However, Gelrite between 6 to $12 \mathrm{~g} / \mathrm{L}$ produced somatic embryos with $9 \mathrm{~g} / \mathrm{L}$ initiated the maximum number of somatic embryos in all three varieties (Table 2). ABA supplemented media significantly affected to initiate somatic embryos and MS-B5 supplemented $10 \mathrm{mg} / \mathrm{LABA}, 10 \mathrm{~g} / \mathrm{L}$ maltose and $9 \mathrm{~g} / \mathrm{L}$ Gelrite produced highest number $(75 \%)$ of somatic embryos in MRQ 80 (Fig. 1a, b). Whereas, lowest number of somatic embryos $(5 \%)$ were obtained from $5 \mathrm{mg} / \mathrm{L}$ ABA supplemented media in all three varieties (Table 2). It was observed that sucrose was not found to be a suitable carbon source for MRQ 74 and showed lower the initiation of somatic embryos in MRQ 80 and MRQ 50. The combination of 
Table 2: Effect of agar, ABA and carbon sources on percentage of somatic embryos initiation after 1-2 months of treatments

\begin{tabular}{|c|c|c|c|c|c|c|c|}
\hline \multirow[t]{2}{*}{ Varieties } & \multirow{2}{*}{$\begin{array}{c}\text { ABA } \\
(\mathrm{mg} / \mathrm{L})\end{array}$} & \multirow{2}{*}{$\begin{array}{l}\text { Carbon } \\
\text { sources } \\
\text { (g/L) }\end{array}$} & & \multicolumn{4}{|c|}{ Somatic embryos initiation (\%) } \\
\hline & & & & $\begin{array}{c}\text { Gelrite } \\
3 \mathrm{~g} / \mathrm{L}\end{array}$ & $\begin{array}{c}\text { Gelrite } \\
6 \mathrm{~g} / \mathrm{L}\end{array}$ & $\begin{array}{c}\text { Gelrite } \\
9 \mathrm{~g} / \mathrm{L}\end{array}$ & $\begin{array}{l}\text { Gelrite } \\
12 \mathrm{~g} / \mathrm{L}\end{array}$ \\
\hline \multirow[t]{8}{*}{ MRQ74 } & 5 & Sucrose & 10 & 0 & 0 & 0 & 0 \\
\hline & & & 30 & 0 & 0 & 0 & 0 \\
\hline & & Maltose & 10 & 0 & 0 & $15 \pm 3$ & $5 \pm 1$ \\
\hline & & & 30 & 0 & 0 & $10 \pm 3$ & $10 \pm 1$ \\
\hline & 10 & Sucrose & 10 & 0 & 0 & 0 & 0 \\
\hline & & & 30 & 0 & 0 & $10 \pm 2$ & 0 \\
\hline & & Maltose & 10 & 0 & 0 & $10 \pm 5$ & $10 \pm 2$ \\
\hline & & & 30 & 0 & 0 & 0 & 0 \\
\hline \multirow[t]{8}{*}{ MRQ80 } & 5 & Sucrose & 10 & 0 & 0 & 0 & 0 \\
\hline & & & 30 & 0 & $5 \pm 1$ & $30 \pm 3$ & $10 \pm 2$ \\
\hline & & Maltose & 10 & 0 & $10 \pm 1$ & $65 \pm 5$ & $20 \pm 1$ \\
\hline & & & 30 & 0 & 0 & $40 \pm 5$ & 0 \\
\hline & 10 & Sucrose & 10 & 0 & $15 \pm 4$ & $35 \pm 3$ & $10 \pm 1$ \\
\hline & & & 30 & 0 & $25 \pm 5$ & $45 \pm 3$ & $20 \pm 4$ \\
\hline & & Maltose & 10 & 0 & $45 \pm 7$ & $75 \pm 5$ & $30 \pm 34$ \\
\hline & & & 30 & 0 & $20 \pm 3$ & $30 \pm 3$ & 0 \\
\hline \multirow[t]{8}{*}{ MRQ50 } & 5 & Sucrose & 10 & 0 & 0 & $5 \pm 1$ & $20 \pm 5$ \\
\hline & & & 30 & 0 & $5 \pm 2$ & $45 \pm 6$ & $25 \pm 1$ \\
\hline & & Maltose & 10 & 0 & $20 \pm 5$ & $55 \pm 6$ & $30 \pm 6$ \\
\hline & & & 30 & 0 & $10 \pm 3$ & $20 \pm 5$ & 0 \\
\hline & 10 & Sucrose & 10 & 0 & 0 & $15 \pm 3$ & 0 \\
\hline & & & 30 & 0 & $25 \pm 5$ & $35 \pm 5$ & $10 \pm 3$ \\
\hline & & Maltose & 10 & 0 & $35 \pm 6$ & $70 \pm 8$ & $20 \pm 1$ \\
\hline & & & 30 & 0 & $20 \pm 3$ & $45 \pm 3$ & 0 \\
\hline
\end{tabular}

The data represent the mean values \pm standard error. Standard errors (SE) were determined by Turkey's multiple range tests at $P<0.05$ level of significance

6-9 g/L Gelrite, $10 \mathrm{mg} / \mathrm{L}$ ABA supplemented MS-B5 medium initiated good somatic embryos in MRQ 80 and MRQ 50. Therefore this treatment was used in the following experiments for regeneration of rice plantlets. Generally, it is well known that carbohydrates not only function as a potential carbon source for metabolism, but also play an important role in the regulation of osmotic potential (Naqvi et al., 2006). Inclusion of maltose in regeneration medium enhanced the regeneration frequency of four japonica upland rice varieties from 27.6 to $43.3 \%$ (Geng et al., 2008). Huang et al. (2012) reported that IAA and $A B A$ was very important for organ differentiation and MS medium supplemented with $10 \mu \mathrm{M}$ IAA and $10 \mu \mathrm{M}$ ABA initiated maximum embryogenic callus (80\%) in rice plantlets. Auxin such as NAA enhances putrescine biosynthesis result in an increase of the putrescine/ spermidine ratio which controlled genetically callus browning trait (Friedman et al., 1985).

\section{Histological analysis of somatic embryogenesis}

The origin and the developmental methods of somatic embryogenesis in rice were determined by histological analysis. After pre-incubation, the histological sections of embryogenic callus demonstrated intensive mitotic divisions from vicinities of the vascular bundles which provided rise to globular pro-embryogenic masses (gpm) (Fig. 1c, d). The histological analysis also revealed the enlargement of the globular embryo (ge) directly from the callus tissue by its distinct shape (Fig. 1c, d). The intense metabolic and mitotic activity at these sites caused them to expand and emerge rapidly from the callus. The cells of somatic embryos were exhibited dense cytoplasm and reduced number of vacuoles. The intense metabolic and mitotic activity at these sites caused them to expand and emerge rapidly from the callus. The cells of somatic embryos were exhibited dense cytoplasm and reduced number of vacuoles. Feher et al. (2003) reported that meristematic cells have to be dedifferentiated and their cell division cycle has to be activated during the transition from somatic to embryogenic states. Similar observations were also reported in other monocot species of Curcuma longa (Raju et al., 2015), Cocus nucifera (Buffard-Morel et al., 1992), Elaeis guineensis (Schwandiman et al., 1988), Phoenix dactylifera (Sane'et al., 2006), dicot species of Manihot esculenta (Baba et al., 2008) and Petiveria alliacea (Cantelmo et al., 2013).

\section{Regeneration of rice plantlets}

For regeneration, whitish somatic embryos cultured on pre-regeneration medium (MS-B5 supplemented with $1.5 \mathrm{mg} / \mathrm{L} \mathrm{BAP}, 1 \mathrm{mg} / \mathrm{L} \mathrm{2}$, 4-D, $10 \mathrm{mg} / \mathrm{L} \mathrm{NAA}$ and $10 \mathrm{mg} / \mathrm{L} \mathrm{ABA}$ ) and tested on suitable carbon sources with Gelrite concentration. The frequency of green somatic embryos was greatly influenced by carbon sources with agar concentration and the best results achieved at $10 \mathrm{~g} / \mathrm{L}$ maltose and $9 \mathrm{~g} / \mathrm{L}$ of Gelrite supplemented media for all varieties (Table 3). The maximum number of plantlets (14\%) was recorded from the variety of MRQ 50, which was statistically similar to variety of MRQ 80 and the lowest number of plantlets $(2 \%)$ was observed in the variety of MRQ 74 (Fig. 1e, f, g, h; Table 3).

In this study, although green somatic embryos occurred with 10 and $30 \mathrm{~g} / \mathrm{L}$ of maltose, higher masses occurred more frequently with maltose compared to sucrose. Maltose between 10 and $30 \mathrm{~g} / \mathrm{L}$ was more conducive to development of somatic embryos compared to sucrose. Similar results were recorded for regenerated rice plantlets using maltose at 10 and $30 \mathrm{~g} / \mathrm{L}$ which produce higher number of regenerated plantlets (Fig. 1h; Table 3). Chemical desiccation using maltose instead of sucrose in MS medium proved to be best for the improvement of both development of green somatic embryos and their regeneration into rice plantlets. It was also noted that regeneration without somatic embryo induction medium with maltose caused callus to become darker and browning appearances were observed (Fig. 1f). Production of embryogenic callus with high regeneration 

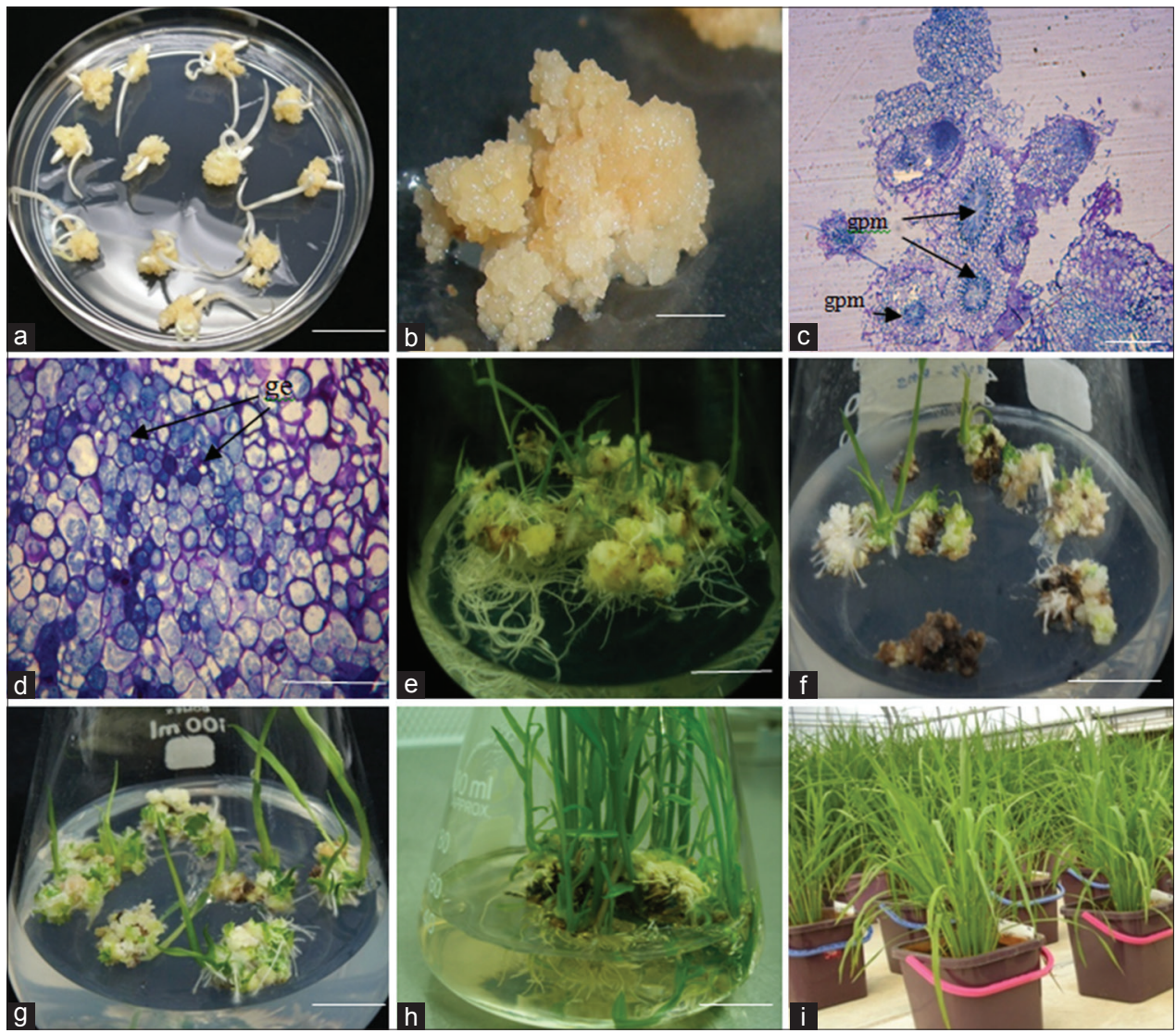

Fig 1. Regeneration of aromatic rice plantlets via somatic embryogenesis system. Callus initiation and proliferation of embryogenic callus (a-b), histological observation of embryogenic callus in early stage of globular pro-embryo, 50X (c) and 200X (d), early phase regeneration of somatic embryogenesis rice MRQ 80 (e), MRQ 74 (f) and MRQ 50 (g), regeneration of rice plantlets in regeneration medium (h) and potted rice plants grown in glasshouse (i). GPM: Gpro-embryogenic mass, GE: Globular embryo and Bars in a, b =1cm; c, $d=100 \mu \mathrm{m} ; \mathrm{e}, \mathrm{f}, \mathrm{g}, \mathrm{h}=2 \mathrm{~cm}$.

Table 3: Effect of carbon sources and agar on the number of regenerated plantlets of three Malaysian aromatic rice varieties

\begin{tabular}{|c|c|c|c|c|}
\hline \multirow{2}{*}{$\frac{\text { Varieties }}{\text { MRQ74 }}$} & \multicolumn{2}{|c|}{ Carbon sources (g/L) } & \multirow{2}{*}{$\frac{\text { Gelrite } 6 \mathbf{~ g} / \mathbf{L}}{0}$} & \multirow{2}{*}{$\frac{\text { Gelrite } 9 \mathrm{~g} / \mathrm{L}}{0}$} \\
\hline & Sucrose & 10 & & \\
\hline & & 30 & 0 & 0 \\
\hline & Maltose & 10 & 0 & $2 \pm 0.5$ \\
\hline & & 30 & 0 & 0 \\
\hline \multirow[t]{4}{*}{ MRQ80 } & Sucrose & 10 & 0 & 0 \\
\hline & & 30 & 0 & 0 \\
\hline & Maltose & 10 & $4 \pm 0.5$ & $13 \pm 3$ \\
\hline & & 30 & $3 \pm 0.5$ & $8 \pm 1$ \\
\hline \multirow[t]{4}{*}{ MRQ50 } & Sucrose & 10 & 0 & 0 \\
\hline & & 30 & $2 \pm 0.1$ & $5 \pm 1$ \\
\hline & Maltose & 10 & $6 \pm 0.3$ & $14 \pm 3$ \\
\hline & & 30 & $3 \pm 0.4$ & $7 \pm 1$ \\
\hline
\end{tabular}

The data represent the mean values \pm standard error. Standard errors (SE) were determined by Turkey's multiple range tests at $P<0.05$ level of significance

capacity is a prerequisite for highly efficient genetic transformation in rice.

\section{Acclimatization of in vitro grown palnts}

The shoots produced, healthy were transferred for acclimatization. The roots appeared within 3 weeks during the acclimatization process and no morphological changes were observed after transfer to large pots and grown in the greenhouse (Fig. 1i). After 117 - 125 days, all the rice plantlets from the three varieties attained maturity with all plants reaching $74-100 \mathrm{~cm}$ in height and produced numerous grains.

\section{CONCLUSION}

The present study confirmed the production of embryogenic callus, somatic embryos as well as regeneration of plantlets in MRQ 74, MRQ 80 and MRQ 50 aromatic rice varieties were established. The somatic embryogenesis was confirmed through histology studies. As a result, MS-B5 medium supplemented with $1.5 \mathrm{mg} / \mathrm{L}$ BAP, $1 \mathrm{mg} / \mathrm{L} 2$, 4-D, $10 \mathrm{mg} / \mathrm{L} \mathrm{NAA}, 10 \mathrm{mg} / \mathrm{L} \mathrm{ABA}, 10 \mathrm{~g} / \mathrm{L}$ maltose and $9 \mathrm{~g} / \mathrm{L}$ Gelrite is a suitable combination for somatic embryogenic callus induction as well as plant regeneration for all studied aromatic rice varieties.

\section{ACKNOWLEDGMENTS}

The authors would like to thank to the Malaysian Ministry of Science and Technology (MOSTI) and MARDI for supporting grant for this research work. 


\section{Author contributions}

Z. A. R.: Were involved in overall planning, conceived the idea, and designed the experiments. A. R.: Made a major contribution to conducting experiments. H. H.: Made a major contribution to conducting experiments. R. K.: Made a major contribution to conducting experiments. Z. A. S.: Made a major contribution to conducting experiments. A. N. O.: Made a major contribution to conducting experiments. Z. Z.: Made a major contribution to conducting experiments. J. U.: Carry out statistical analysis and contributed in writting. S. S.: Were involved in overall planning and improvement of article.

\section{REFERENCES}

Afrasiab, H. and R. Jafar. 2011. Effect of different media and solidifying agents on callogenesis and plant regeneration from different explants of rice (Oryza sativa) varieties super Basmati and IRRI-6. Pak. J. Bot. 43(1): 487-501.

Baba, A. I., F. C. S. Nogueira, C. B. Pinheira, J. N. Brasil, E. S. Jereissati, T. L. Juca, A. A. Soares, M. F. Santos, G. B. Domont and F A. P. Campos. 2008. Proteome analysis of secondary somatic embryogenesis in cassava (Manihot esculenta). Plant Sci. 175: 717-723.

Barandiaran, X., A. D. Pietro and J. Martin. 1999. Biolistic transfer and expression of a uidA reporter gene in different tissues of Allium sativum L. Plant Cell Rep. 17: 737-741.

Buffard-Morel, J., J. L. Verdeil and C. Pannetier. 1992. Embryogenese somatique du cocotier (Cocos nucifera L.) a partir d'explants foliaires: Etudes histologiques. Can. J. Bot. 70: 735-741.

Cantelmo, L., B. O. Soares, L. P. Rocha, J.A. Pettinelli, C. H. Callado, E. Mansur, A. Castellar and R. F. Gagliardi. 2013. Repetitive somatic embryogenesis from leaves of the medicinal plant Petiveria alliacea L. Plant Cell Tiss. Organ Cult. 115: 385-393.

Cheng, W., H. Sakai, K. Yagi and T. Hasegawa. 2010. Combined effects of elevated $\left[\mathrm{CO}_{2}\right]$ and high night temperature on carbon assimilation, nitrogen absorption, and the allocations of $\mathrm{C}$ and $\mathrm{N}$ by rice (Oryza sativa L.). Agric. For. Meteorol. 150(9): 1174-1181.

Chu, C. C., C. C. Wang, C. S. Sun, C. Hsu, K. C. Yin and C. Y. Chu. 1975. Establishment of an efficient medium for anther culture in rice through comparative experiments on the nitrogen sources. Sci. Sin. 18: 659-668.

Deo, P. C., R. H. Harding, M. Taylor, A. P. Tyagi and D. K. Becker. 2009. Somatic embryogenesis, organogenesis and plant regeneration in taro (Colocasia esculenta var. esculenta). Plant Cell Tiss. Organ Cult. 99: 61-71.

Ding, Z. and J. Frimla. 2010. Auxin regulates distal stem cell differentiation in Arabidopsis roots. PNAS. 107: 26.

Feher, A., T. P. Pasternak and D. Dudits. 2003. Transition of somatic cells to an embryogenic state. Plant Cell Tiss. Organ Cult. 74: 201-228.

Friedman, R., A. Altman and U. Bachrach. 1985. Polyamines and root formation in mung bean hypocotyls cuttings. II. Incorporation of precursors into polyamines. Plant Physiol. 79: 80-83.

Hadeler, B., S. Scholtz and R. Reski. 1995. Gelrite and agar differently influence cytokinin-sensitivity of a moss. J. Plant Physiol. 146: 369-371.

Hashemi, F. S. G., M. Y. Rafi, M. R. Ismail, M. T. M. Mohamed, H A. Rahim, M. A. Latif and F. Aslani. 2015. The genetic and molecular origin of natural variation for the fragrance trait in an elite Malaysian aromatic rice through quantitative trait loci mapping using SSR and gene-based markers. Gene. 555: 101-107.

Hashemi, F. G., M. Y. Rafii, M. R. Ismail, T. M. M. Mahmud, H. A. Rahim, R. Asfaliza, M. Malek and M. A. Latif. 2013. Biochemical, genetic and molecular advances of fragrance characteristics in rice. Crit. Rev. Plant Sci. 32: 445-457.

Huang, W. L., C. H. Lee and Y. R. Chen. 2012. Levels of endogenous abscisic acid and indole-3-acetic acid influence shoot organogenesis in callus cultures of rice subjected to osmotic stress. Plant Cell Tiss. Organ Cult. 108: 257-263.

Ilahi, I., S. Bano, N. Jabeen and F. Rahim. 2005. Micropropagation of rice (Oryza sativa L. cv. Swat-II) through somatic embryogenesis. Pak. J. Bot. 37(2): 237-242.

Jain, S., A. Varshney and S. L. Kothari. 1995. Embryogenic callus induction and efficient plant regeneration in Proso millet. Cereal Res. Commun. 29: 313-320.

Jiang, T. Y., J. Jiang, R. K. Xu and Z. Li. 2012. Adsorption of Pb (II) on variable charge soils amended with rice-straw derived biochar. Chemosphere. 89(3): 249-256.

Kaushal, L., S. M. Balachandran, K. Ulaganathan, A. K. Singh, R. Priyadarshi and V. Shenoy. 2015. Auxin to improve green plant regeneration of rice anther culture. Int. J. Agric. Crop Sci. 8(1): 15-26.

Kaushal, L., S. M. Balachandran, K. Ulaganathan and V. Shenoy. 2014a. Effect of media on improving anther culture response of rice (Oryza sativa L.). Int. J. Agric. Innov. Res. 3(1): 218-224.

Kaushal, L., R. Sharma, S. M. Balachandran, K. Ulaganathan and V. Shenoy. 2014b. Effect of cold pretreatment on improving anther culture response of rice (Oryza sativa L.). J. Exp. Biol. Agric. Sci. 2: 233-242.

Khatun, R., S. M. S. Islam, I. Ara, N. Tuteja and M. A. Bari. 2012. Effect of cold pretreatment and different media in improving anther culture response in rice (Oryza sativa L.) in Bangladesh. Indian J. Biotech. 11(4): 458-463.

Klimaszewska, K., M. Bernier-Cardou, D. Cyr and B. Sutton. 2000. Influence of gelling agents on culture medium gel strength, water availability, tissue water potential and maturation response in embryogenic cultures of Pinus strobes L. In Vitro Cell Dev. Biol Plant. 36: 279-289.

Klimaszewska, K., Y. Devantier, D. Lachance, M. A. Lelu and P. J. Charest. 1997. Larix laricina (tamarack) somatic embryogenesis and genetic transformation. Can. J. For. Res. 27: $538-550$.

Lainé, E., F. Lamblin, J. Lacoux, P. Dupre, D. Roger, D. Sihachakr and A. David. 2000. Gelling agent influences the detrimental effect of kanamycin on adventitious budding in flax. Plant Cell Tiss. Organ Cult. 63: 77-80.

Lee, S. T. and W. L. Huang. 2014. Osmotic stress stimulates shoot organogenesis in callus of rice (Oryza sativa L.) via auxin signaling and carbohydrate metabolism regulation. Plant Growth Regul. 73: 193-204.

Mo, Z., W. Li, S. Pan, T. L. Fitzgerald, F. Xia, Y. Tang, Y. Wang, M. Duan, H. Tian and X. Tang. 2015. Shading during the grain filling period increases 2-acetyl-1-pyrroline content in fragrant rice. Rice. 8: 9.

Murashige, T. and F. Skoog. 1962. A revised medium for rapid growth and bioassay with tobacco tissue cultures. Physiol. Plant. 15: 473-497.

Myint, K. K. M., H. Yasui, M. Takagi and M. Matsumura. 2009. Virulence of long-term laboratory populations of the brown planthopper, Nilaparvata lugens (Stal), and whitebacked planthopper, 
Sogatella furcifera (Horvath) (Homoptera: Delphacidae), on rice differential varieties. Appl. Entomol. Zool. 44(1): 149.

Naqvi, S. M. S., T. Sultana, T. Yasmin, T. Mahmood and M. H. Akhtar. 2006. Efficient embryogenic system from tissue culture of mature embryos for some coarse varieties of rice (Oryza sativa L.). Pak. J. Bot. 38: 969-975.

Pérez, M., M. Viejo, M. Lacuesta, P. Toorop and M. J. Cañal. 2015. Epigenetic and hormonal profile during maturation of Quercus suber L. somatic embryos. J. Plant Physiol. 173: 51-61.

Rademacher, E., A. Lokerse, A. Schlereth, C. Llavata-Peris, M. Bayer, M. Kientz, A. Freire Rios, J. Borst, W. Lukowitz, G. Jürgens and D. Weijers. 2012. Different auxin response machineries control distinct cell fates in the early plant embryo. Dev. Cell. 22: 211-222.

Raju, C. S., A. Aslam and A. Shajahan. 2015. High-efficiency direct somatic embryogenesis and plant regeneration from leaf base explants of turmeric (Curcuma longa L.). Plant Cell Tiss. Organ Cult. 122(1): 79-87.

Rossin, C. B. and M. E. C. Rey. 2011. Effect of explant source and auxins on somatic embryogenesis of selected cassava (Manihot esculenta Crantz) cultivars. S. Afr. J. Bot. 77: 59-65.

Sané, D., F. Aberlenc-Bertossi, Y. K. Gassama-Dia, M. Sagna, M. F. Trouslot, Y. Duval and A. Borgel. 2006. Histological analysis of callogenesis and somatic embryogenesis from cell suspensions of date palm (Phoenix dactylifera). Ann. Bot. 98: 301-308.

Schwandiman, J., C. Pannetier and N. Michaux-Ferriere. 1988. Histology of somatic embryogenesis from leaf explants of the oil palm Elaeis guineensis. Ann. Bot. 62: 43-52.

Sakthivel, K., N. Shobha Rani, M. K. Pandev, A. K. P. Sivaranjani,
C. N. Neeraja, S. M. Balachandran, M. Sheshu Madhav, B. C. Viraktamath, G. S. V. Prasad and R. M. Sundaram. 2009a. Development of a simple functional marker for fragrance in rice and its validation in Indian Basmati and non-Basmati fragrant rice varieties. Mol. Breed. 24: 185-190.

Sarhadi, W. A., N. L. Hien, M. Zanjani, W. Yosofzai, T. Yoshihashi and Y. Hirata. 2008. Comparative analysis for aroma and agronomic traits of native rice cultivars from central Asia. J. Crop Sci. Biotechnol. 11: 17-22.

Siddique, A. B., I. Ara, S. M. S. Islam and N. Tuteja. 2014. Effect of air desiccation and salt stress factors on in vitro regeneration of rice (Oryza sativa L.). Plant Signal. Behav. 9(12): e977209.

Su, Y. H., X. Y. Zhao, Y. B. Liu, C. L. Zhang, S. D. O'Neill and X. S. Zhang. 2009. Auxin-induced WUS expression is essential for embryonic stem cell renewal during somatic embryogenesis in Arabidopsis. Plant J. 59: 448-460.

Thengane, S. R., S. R. Deodhar, S. V. Bhosle and S. K. Rawak. 2006. Repetitive somatic embryogenesis and plant regeneration in Garcinia indica Choiss. In Vitro Cell Dev. Biol. Plant. 42: 256-261.

Triqui, Z., A. Guedira, A. Chlyah, V. Souvannavong, R. Haicour and D. Sihachakr. 2008. Effect of genotype, gelling agent, and auxin on the induction of somatic embryogenesis in sweet potato (Ipomoea batatas Lam.). C. R. Biol. 331: 198-205.

Vega, R., N. Vasquez, A. M. Espinoza, A. M. Gatica and M. V. Melara. 2009. Histology of somatic embryogenesis in rice (Oryza sativa cv. 5272). Rev. Biol. Trop. 57: 141-150.

Zuraida, A. R., B. Naziah, Z. Zamri and S. Sreeramanan. 2011. Efficient plant regeneration of Malaysian indica rice MR 219 and 232 via somatic embryogenesis system. Acta Physiol. Plant. 33 1913-1921. 